\title{
MUTU KIMIA DAN ORGANOLEPTIK ABON IKAN TONGKOL (Euthynnus affinis) PADA BERBAGAI LAMA PENGGORENGAN
}

\author{
Renol $^{1)}$, Finarti ${ }^{1)}$, Mohamad Akbar'), Deddy Wahyudi ${ }^{1)}$ \\ ${ }^{1}$ Sekolah Tinggi Perikanan dan Kelautan-STPL \\ Jl. Soekarno Hatta KM 6 Palu, Sulawesi Tengah, Indonesia \\ Email : renolstpl@yahoo.com
}

\begin{abstract}
Abon ikan adalah suatu olahan daging ikan yang dibuat menjadi produk melalui proses kombinasi penggilingan, penggorengan, pengeringan, dengan cara menggoreng serta penambahan bahan penyedap. Penggorengan merupakan suatu proses pemanasan bahan pangan menggunakan medium minyak goreng sebagai pengantar panas. Tujuan penelitian untuk mengetahui mutu kimia (Kadar lemak, Kadar Air dan Kadar Abu) dan mutu organoleptik abon ikan tongkol dari berbagai lama penggorengan. Penelitian ini menggunakan rancangan acak lengkap dengan perlakuan dan ulangan sehingga terdapat $4 \times 4=16$ unit percobaan. Adapun perlakuan yang dicobakan yaitu: L1 = lama penggorengan 30 menit, L2 = lama penggorengan 35 menit, L3 = lama penggorengan 40 menit, L4 = lama penggorengan 45 menit. Hasil penelitian menunjukan perlakuan perbedaan lama penggorengan yang berpengaruh sangat nyata $(p<0,01)$ terhadap kadar air, lemak dan kadar abu, serta sifat sensorik kenampakan, aroma, rasa dan bau abon ikan tongkol. Hasil uji BNJ menunjukan untuk kadar lemak pada perlakuan 30 menit $(17,27 \%)$ lebih baik dibandingkan pada perlakuan 35 menit (21,64\%), 40 menit $(25,29 \%)$ dan 45 menit (26,60\%), kadar air diperoleh 6,09\% pada perlakuan 45 menit lebih baik dibandingkan perlakuan 30 menit $(21,68 \%), 35$ menit $(13,12)$ dan 40 menit (11,56), sedangkan kadar abu perlakuan 30 menit $(5,35 \%), 35$ menit $(5,40 \%), 40$ menit (5,99\%), dan 45 menit (5,77\%). Mutu organoleptik yang meliputi tampilan, Aroma dan Tekstur menjadi yang terbaik pada perlakuan lama penggorengan 30 menit sedangkan untuk rasa yang terbaik pada perlakuan 40 menit.
\end{abstract}

Kata Kunci : Ikan tongkol, abon, penggorengan, mutu kimia dan organoleptic

\section{PENDAHULUAN}

Salah satu sumber protein bagi manusia adalah Ikan. Ikan dapat memenuhi kebutuhan protein hewani di sejumlah negara. mengkonsumsi ikan dapat dipercaya memberikan efek kesehatan tubuh. sumber makanan yang kaya akan asam lemak tak jenuh terdapat pada Ikan laut. Senyawa ini telah banyak dibuktikan memberikan efek positif bagi kesehatan, seperti menurunkan resiko penyakit jantung, kanker, artritis, dan lain-lain (Berghe dan Barnathan, 2005)

$$
\text { Secara umum ikan cepat }
$$

mengalami pembusukan apabila dibandingkan dengan bahan makanan lain. pembusukan pada ikan yang disebabkan oleh perubahan faktor kimiawi dan Bakteri. Berdasarkan pada kenyataan ini maka dibutuhkan teknologi pengawetan ikan ataupun olahan ikan sehingga dapat memperpanjang umur simpannya, diantaranya inovasi pengolahan ikan menjadi abon ikan (Kusumayanti $d k k$, 2011).

Abon ikan adalah suatu olahan hasil perikanan yang dibuat dari daging ikan menjadi sebuah produk melalui proses kombinasi penggilingan, penggorengan, pengeringan, dengan cara menggoreng dan menambahkan bahan penyedap. Mutu produk olahan abon ikan dipengaruhi oleh mutu bahan mentah, cara pengolahannya 
dan nilai gizi yang dikandungnya (Karyono dan Wachid, 1982)

Pembuatan abon dilakukan penambahan bumbu-bumbu yang yang terdiri dari bawang putih, bawang merah, ketumbar, gula merah, dan garam. Penambahan bumbu menghasilkan aroma dan cita rasa positif sehingga makanan lebih disukai.

Penggorengan merupakan proses pemanasan bahan pangan menggunakan media minyak goreng sebagai pengantar panas. Sifat fisik, kimia, dan sifat sensorik Selama proses penggorengan akan mengalami perubahan. Reaksi komplek yang terjadi pada minyak disaat itu minyak mengalami kerusakan, apabila menggoreng dengan suhu yang tinggi. Menurunnya efisiensi penggorengan dan kualitas produk akhir disebabkan berlebihnya angka yang ditetapkan oleh kerusakan minyak yang berlanjut. Oleh karena itu lama penggorengan menggunakan 30 menit sampai 45 menit bisa menjadi alternatif cara penggorengan yang lama sehingga bisa meminimalkan kerusakan minyak dan memaksimalkan kualitas produk akhir (Muchtadi, 2008).

Menurut Aminah (2009), Kegiatan memanaskan minyak untuk keperluan menggoreng dengan waktu yang bisa ditentukan disebut waktu penggorengan. Menggoreng bahan makanan yang diperuntukan untuk dijual membutuhkan waktu yang lama dibandingkan menggoreng dalam jumlah yang sedikit dibutuhkan waktu yang lebih sedikit yaitu rata-rata waktu yang digunakan selama 15 30 menit.

Untuk setiap jenis makanan untuk ikan laut, ikan asin, ayam, telur dan pindang minyak yang digunakan tidak dibedakan. Sedangkan untuk makanan yang dikonsumsi untuk keluarga dan dijual biasa berbeda kalau untuk dijual terdiri dari pisang, tahu isi, pia-pia, ubi dan lain-lain. Dan untuk dikonsumsi keluarga responden menyatakan sama terdiri dari tempe, tahu, ikan laut, kerupuk, telur dan lain-lain.

Penelitian ini bertujuan untuk mengetahui mutu kimia (Kadar lemak, Kadar Air dan Kadar Abu) dan mutu organoleptik abon ikan tongkol dari berbagai lama penggorengan.

\section{METODE PENELITIAN}

Penelitian ini dilaksanakan di Laboratorium Teknologi Hasil Ternak Jurusan Peternakan Fakultas Peternakan dan Perikanan Universitas Tadulako. Bahan yang digunakan dalam penelitian ini adalah ampas ikan tongkol, rempah-rempah (bawang merah, bawang putih, ketumbar, irisan lengkuas, daun salam, sereh, gula merah, asam jawa), dan santan. Peralatan yang digunakan adalah pisau, alat perajang (talenan), ember plastik, keranjang plastik, panci, baskom, alat penghancur bumbu (cobek), penggorengan (wajan), parutan, garpu, kantong plastik, kain blacu, alat tekan (pres).

Penelitian ini menggunakan rancangan acak lengkap (RAL) dengan 4 perlakuan dan 4 ulangan sehingga keseluruhan ada 16 unit percobaan. Adapun perlakuan yang dicobakan yaitu:

L1 = lama penggorengan 30 menit

L2 = lama penggorengan 35 menit

L3 = lama penggorengan 40 menit

L4 = lama penggorengan 45 menit

Menurut Apriyantono dkk (1989) Analisi lemak dilakukan dengan menggunakan metode soxhlet labu yang sesuai ukurannya dengan alat ekstraksi soxhlet dikeringkan dalam oven lalu didinginkan dalam desikator dan ditimbang. Sebanyak 5 gram sampel ditimbang dalam saringan timbal yang sesuai ukurannya. Kemudian sampel ditutup dengan kapas wol bebas lemak atau dengan menggunakan kertas saring. Timbal atau kertas saring yang berisi sampel diletakan dalam ekstraksi soxhlet lalu kondensor dipasang di atasnya dan labu lemak dibawahnya. Refluksi dilakukan selama 5 jam sampai pelarut yang turun kembali ke labu lemak berwarna jernih. Pelarut yang ada dalam labu lemak didestilasi dan ditampung pelarutnya. Selanjutnya labu yang berisi lemak hasil ekstraksi dipanaskan dalam oven pada suhu $105^{\circ} \mathrm{C}$. Setelah didapatkan berat yang tepat, lemak dalam labu tersebut didinginkan dalam desikator dan 
selanjutnya lemak beserta labunya ditimbang. Perhitungan kadar lemak sebagai berikut :

Kadar Lemak $=\frac{\text { Berat Lemak }}{\text { Berat Sampel }} \times 100 \%$

Winarno, (1997). Prosedur kerja pengukuran kadar air sebagai berikut ;

1. Cawan kosong dan tutupnya dikeringkan dalam oven selama 15 menit.

2. Sampel dihomogenkan dalam cawan lalu ditimbang kurang lebih $5 \mathrm{~g}$.

3. Sampel yang berada dalam cawan dimasukkan dalam oven selama 3 jam.

4. Selama 3-5 menit Cawan didinginkan, selanjutnya bahan ditimbang

5. Untuk menentukan berat konstan atau tetap Bahan dikeringkan kembali dalam oven 30 menit.

Kadar air dihitung dengan rumus :

$$
\% \text { Kadar Air : } \frac{\text { berat awal-berat akhir }}{\text { Berat awal }} \times 100 \%
$$

Menurut Irawati, (2008) pemanasan dengan suhu 500-600 derajat celcius merupakan prinsip menganalisa kadar abu yaitu dengan cara dikeringkan ditanur dengan melihat sisa abu atau mineral yang terdapat pada bahan yang di uji. Pengabuan kering untuk menentukan total abu, abu larut, tidak larut air dan tidak larut asam. Suhu tinggi dapat menyebabkan penguapan unsur-unsur sepert $\mathrm{K}, \mathrm{Na}, \mathrm{S}, \mathrm{Ca}, \mathrm{Cl}$. Sehingga tidak terjadi kehilangan elemen secara mekanis.

Pengamatan perubahan mutu inderawi abon dilakukan secara deskriptif, hedonik (Kesukaan), dan pengamatan visual. Penilaian secara deskriptif yang dilakukan meliputi karakteristik tekstur, aroma, tampilan, dan rasa abon. Skala penilaian deskriptif yang digunakan adalah 1 sampai 9 dengan 30 orang panelis. Data hasil uji organoleptik dianalisis menggunakan Anova dengan uji lanjut BNJ.

\section{HASIL DAN PEMBAHASAN}

\section{Kadar Lemak}

Lemak merupakan zat makanan yang penting untuk kesehatan tubuh manusia. Selain itu lemak juga terdapat pada hampir semua bahan pangan dengan kandungan yang berbeda-beda (Winarno, 2002). Menurut Ketaren (1986), lemak terdiri dari trigliserida campuran, yang merupakan ester dari gliserol dan asam lemak rantai panjang. Lemak tersebut jika dihidrolisis akan menghasilkan 3 molekul asam lemak rantai panjang dan 1 molekul gliserol.

Hasil uji kadar lemak pada abon ikan tongkol yang menggunakan hasil samping ekstrak minyak ikan berkisar anatara $17,27 \%$ sampai $26,60 \%$. Hasil sidik ragam menunjukkan bahwa perlakuan lama penggorengan yang berbeda memberikan pengaruh yang nyata terhadap parameter kadar lemak. Hal ini dapat dilihat $\mathrm{F}$ hitung $>\mathrm{F}$ tabel $5 \%$, selanjutnya untuk mengetahui perbedaan dari masing-masing perlakuan dilakukan uji BNJ. Rata-rata kadar lemak pada abon ikan tongkol yang menggunakan hasil samping ekstrak minyak ikan dapat dilihat pada Gambar 1.

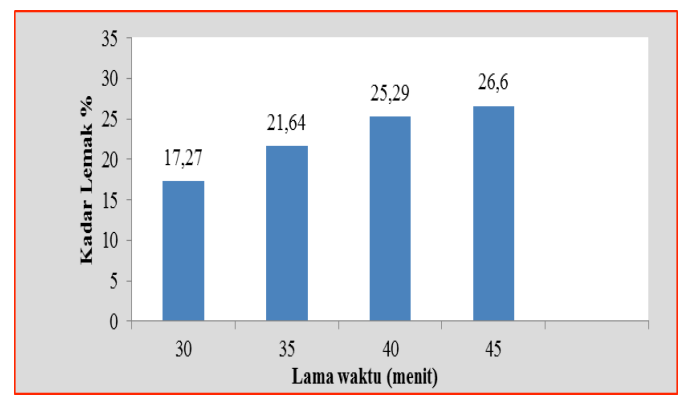

Gambar 1. Diagram rata-rata kadar lemak abon ikan tongkol dengan perlakuan lama penggorengan

Berdasarkan Gambar 1 dapat dilihat bahwa kadar lemak terendah terdapat pada perlakuan dengan lama penggorengan 30 menit yaitu sebesar $(17,27 \%)$ sedangkan kadar lemak tertinggi terdapat pada perlakuan dengan lama penggorengan 45 menit yaitu sebesar (26,60\%). Hal ini menunjukan adanya peningkatan nilai rata-rata kadar lemak 
bahan, semakin lama waktu penggorengan maka nilai kadar lemak akan cenderung naik. Peningkatan tersebut disebabkan banyaknya ruang kosong pada produk penggorengan yang diisi oleh minyak akibat lamanya waktu penggorengan. Hal ini juga dibuktikan oleh (Rosyanti, 2000) yang membuktikan bahwa semakin meningkatnya lama penggorengan maka kadar lemak akan semakin besar.

\section{Kadar Air}

Menurut Sudarmadji dkk. (2007), menimbang bahan sampai konstan berarti semua air sudah diuapkan dengan jalan pemanasan adalah prinsip uji kadar air dengan metode Thermogravimetri.

Hasil uji kadar air abon ikan tongkol yang menggunakan hasil samping ekstrak minyak ikan berkisar antara 21,68\% sampai dengan 6,09\%. Hasil analisis sidik ragam menunjukan bahwa perlakukan dengan lama penggorengan yang berbeda memberikan pengaruh yang sangat nyata terhadap parameter kadar air. Hal ini dapat dilihat $\mathrm{F}$ hitung $>\mathrm{F}$ tabel $5 \%$, selanjutnya untuk mengetahui perbedaan dari masingmasing perlakuan dilanjutkan dengan uji BNJ. Rata-rata kadar air pada abon ikan tongkol yang menggunakan hasil samping ekstrak minyak ikan dapat dilihat pada Gambar 2.

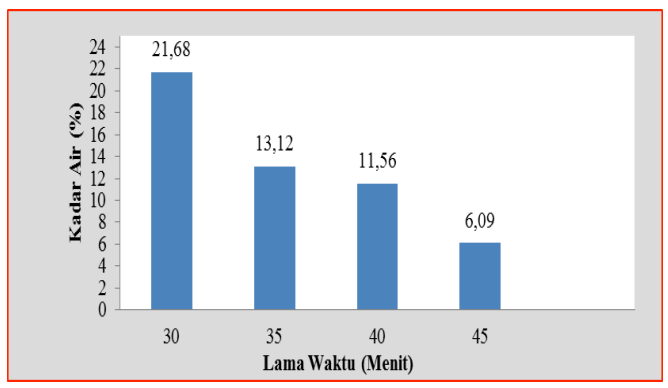

Gambar 2. Diagram rata-rata kadar air abon ikan tongkol dengan perlakuan lama penggorengan

Berdasarkan Gambar 2 dapat dilihat bahwa kadar air tertinggi terdapat pada perlakuan dengan lama penggorengan 30 menit yaitu sebesar $21,68 \%$, sedangkan yang terendah pada perlakuan dengan lama penggorengan 45 menit yaitu sebesar
6,09\%. Penyebab dari menurunnya kadar air adalah akibat panas dari minyak goreng yang menguapkan sejumlah kadar dari bahan. Peningkatan waktu penggorengan akan menurunkan nilai kadar air abon. Semakin lama penggorengan maka semakin banyak air yang akan menguap sehingga semakin tebal renyahan yang terbentuk yang secara otomatis akan diisi dengan penyerapan minyak (Winarti, 2000).

Berdasarkan SNI (1995), persyaratan standar mutu abon secara umum nilai kadar air maksimal 7\%, dan nilai kadar air pada lama penggorengan 30 menit, 35 menit dan 40 menit masih tinggi yaitu masing-masing sebesar 21,68\% sampai $11,56 \%$ sehingga kadar air pada abon ikan tongkol dengan waktu tersebut belum memenuhi persyaratan standar mutu abon, sedangkan pada waktu penggorengan 45 menit yaitu sebesar 6,09\% sehingga memenuhi persyaratan standar mutu abon. Menurut Purnomo (1995), suhu pada saat pengeringan akan mempengaruhi penyerapan kadar air isotermis.

Selain itu, peningkatan suhu pengolahan akan menurunkan kemampuan menahan air yang mungkin disebabkan oleh perubahan akibat pemanasan yang tidak dapat kembali.

\section{Kadar $\mathrm{Abu}$}

Abu adalah zat anorganik sisa hasil pembakaran suatu bahan organik. Komposisi bahan mempengaruhi pengabuannya Kadar abu ada hubungannya dengan mineral suatu bahan. Tujuan dari penentuan abu total adalah melihat parameter nilai gizi bahan makanan dan menentukan baik tidaknya suatu proses pengolahan (Sudarmadji $d k k$., 2007).

Hasil uji kadar abu abon ikan tongkol yang menggunakan hasil samping ekstrak minyak ikan berkisar antara 5,35\% sampai dengan 5,77\%. Hasil analisis sidik ragam menunjukan bahwa perlakukan dengan lama penggorengan yang berbeda memberikan pengaruh yang sangat nyata terhadap parameter kadar abu. Hal ini dapat dilihat $\mathrm{F}$ hitung $>\mathrm{F}$ tabel 5\%, selanjutnya untuk mengetahui perbedaan dari masingmasing perlakuan dilanjutkan dengan uji BNJ. Rata-rata kadar abu pada abon ikan 
tongkol yang menggunakan hasil samping ekstrak minyak ikan dapat dilihat pada Gambar 3.

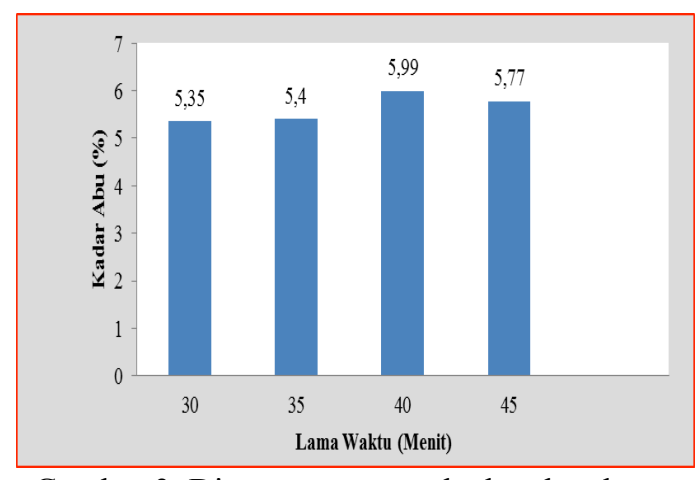

Gambar 3. Diagram rata-rata kadar abu abon ikan tongkol dengan perlakuan lama penggorengan

Berdasarkan Gambar 3 dapat dilihat bahwa kadar abu tertinggi terdapat pada perlakuan dengan lama penggorengan 40 menit yaitu sebesar $5,99 \%$, sedangkan yang terendah pada perlakuan dengan lama penggorengan 30 menit yaitu sebesar $5,35 \%$. hal ini diduga proses penggorengan abon yang lama sehingga kadar air yang ada pada abon rendah dan meninggalkan mineral pada abon yang tinggi sehingga kadar abu meningkat. Sedangkan kadar abu terendah yaitu pada perlakuan lama penggorengan 30 menit dengan nilai ratarata kadar abu sebesar 5,35\%. Hal ini diduga karena tingginya kadar air pada bahan dan tekstur abon yang belum halus sehingga kadar abu rendah.

Berdasarkan SNI (1995), persyaratan standar mutu abon secara umum nilai kadar abu maksimal 7\%, dan nilai kadar abu tertinggi pada abon ikan tongkol yang menggunakan hasil samping ekstrak minyak ikan sebesar 5,99\% sehingga kadar abu pada abon ikan tongkol yang menggunakan ampas sisa ekstrak minyak ikan memenuhi persyaratan standar mutu abon.

\section{Mutu Organoleptik}

\section{Tampilan}

Hasil uji organoleptik tampilan abon ikan tongkol yang menggunakan hasil samping ekstrak minyak ikan berkisar antara 6,75 sampai dengan 5,72. Hasil analisis sidik ragam menunjukan bahwa perlakukan dengan lama penggorengan yang berbeda memberikan pengaruh yang sangat nyata terhadap parameter organoleptik tampilan. Hal ini dapat dilihat $\mathrm{F}$ hitung $>\mathrm{F}$ tabel 5\%, selanjutnya untuk mengetahui perbedaan dari masing-masing perlakuan dilanjutkan dengan uji BNJ. Rata-rata organoleptik tampilan pada abon ikan tongkol yang menggunakan hasil samping ekstrak minyak ikan dapat dilihat pada Gambar 4.

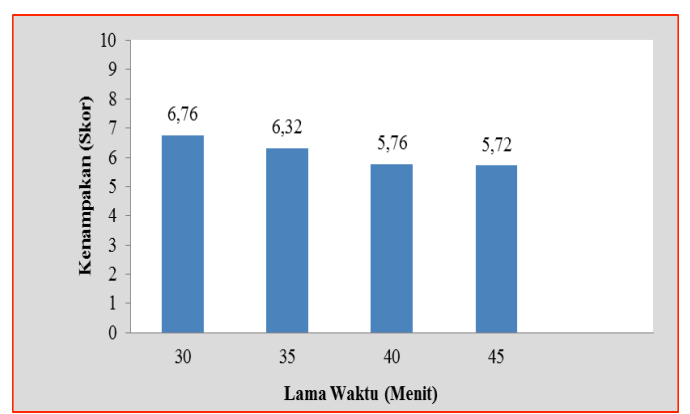

Gambar 4. Diagram rata-rata organoleptik tampilan abon ikan tongkol dengan perlakuan lama penggorengan

Berdasarkan Gambar 4 dapat dilihat bahwa organoleptik tampilan tertinggi terdapat pada perlakuan dengan lama penggorengan 30 menit yaitu sebesar 6,76 sedangkan yang terendah pada perlakuan dengan lama penggorengan 45 menit yaitu sebesar 5,72. Hal ini diduga pada proses penggorengan yang menggunakan waktu yang paling cepat yaitu 30 menit dibanding dengan proses penggorengan abon yang lain, sehingga menghasilkan tekstur yang kompak dan penampakan warna yang paling menarik dan kompak pada saat akhir penggorengan. Oleh karena itu panelis lebih menyukai tampilan pada perlakuan lama penggorengan 30 menit.

$$
\text { Berdasarkan perhitungan }
$$

penerimaan konsumen terhadap organoleptik tampilan menunjukkan bahwa lama penggorengan 30 menit terbaik yaitu sebesar 6,76 kemudian dibulatkan menjadi 7. Secara deskriptif, pada nilai tersebut dapat disimpulkan bahwa tampilan abon ikan disukai panelis. 


\section{Aroma}

Hasil uji organoleptik aroma abon ikan tongkol yang menggunakan hasil samping kestrak minyak ikan berkisar antara 7,36 sampai dengan 6,04. Hasil analisis sidik ragam menunjukan bahwa perlakukan dengan lama penggorengan yang berbeda memberikan pengaruh yang sangat nyata terhadap parameter organoleptik aroma. Hal ini dapat dilihat $\mathrm{F}$ hitung $>\mathrm{F}$ tabel $5 \%$, selanjutnya untuk mengetahui perbedaan dari masing-masing perlakuan dilanjutkan dengan uji BNJ. Rata-rata organoleptik aroma pada abon ikan tongkol yang menggunakan hasil samping ekstrak minyak ikan dapat dilihat pada Gambar 5.

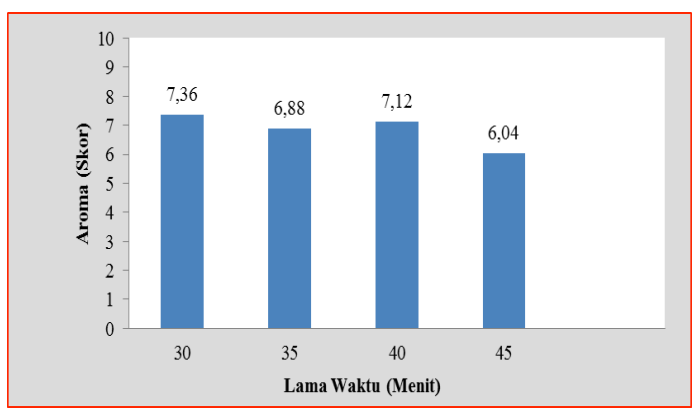

Gambar 5. Diagram rata-rata organoleptik aroma abon ikan tongkol dengan perlakuan lama penggorengan

Berdasarkan Gambar 5 dapat dilihat bahwa organoleptik aroma tertinggi terdapat pada perlakuan dengan lama penggorengan 30 menit yaitu sebesar 7,36 sedangkan yang terendah pada perlakuan dengan lama penggorengan 45 menit yaitu sebesar 6,04. Hal ini diduga aroma abon dipengaruhi oleh perbedaan senyawa penyususn aroma bahan dasarnya yaitu aroma khas daging ikan tongkol yang telah diolah, bumbu-bumbu dan rempah-rempah . Berdasarkan perhitungan penerimaan konsumen terhadap organoleptik aroma menunjukkan bahwa lama penggorengan 30 menit terbaik yaitu sebesar 7,36 kemudian dibulatkan menjadi 7. Disimpulkan bahwa aroma abon ikan disukai panelis.

\section{Rasa}

Rasa ialah sesuatu yang diterima oleh lidah. Asin, pahit, manis, asam dan apabila dilakukan modifikasi ditambah respon adalah tergolong dalam pengindraan cecapan (Zura, 2006). Komponen komponen yang mempengaruhi Rasa adalah senyawa kimia, suhu, konsentrasi dan interaksi dengan komponen rasa yang lain.

Hasil uji organoleptik rasa abon ikan tongkol yang menggunakan hasil samping ekstrak minyak ikan berkisar antara 7,04 sampai dengan 5,64. Hasil analisis sidik ragam menunjukan bahwa perlakukan dengan lama penggorengan yang berbeda memberikan pengaruh yang sangat nyata terhadap parameter organoleptik rasa. Hal ini dapat dilihat $\mathrm{F}$ hitung $>\mathrm{F}$ tabel $5 \%$, selanjutnya untuk mengetahui perbedaan dari masing-masing perlakuan dilanjutkan dengan uji BNJ. Rata-rata organoleptik rasa pada abon ikan tongkol yang menggunakan hasil samping ekstrak minyak ikan dapat dilihat pada Gambar 6.

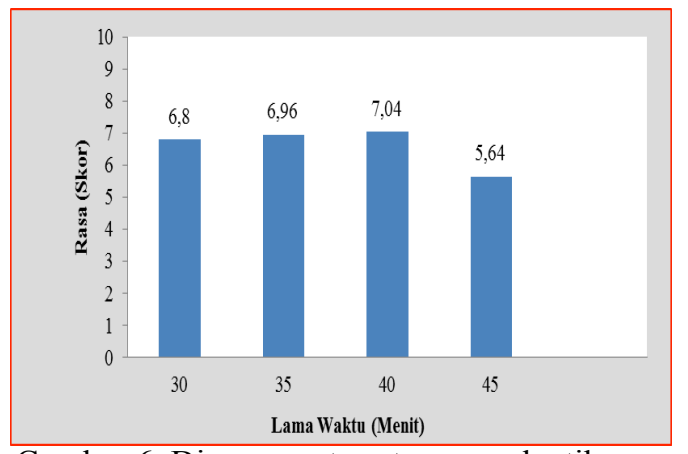

Gambar 6. Diagram rata-rata organoleptik rasa abon ikan tongkol dengan perlakuan lama penggorengan

Berdasarkan Gambar 6 dapat dilihat bahwa organoleptik rasa tertinggi terdapat pada perlakuan dengan lama penggorengan 40 menit yaitu sebesar 7,04 sedangkan yang terendah pada perlakuan dengan lama penggorengan 45 menit yaitu sebesar 5,64. Hal ini diduga pada proses penggorengan dengan lama 40 menit lebih sempurna dibanding dengan abon yang lain, sehingga dihasilkan rasa yang lebih enak. Nilai organoleptik rasa pada abon ikan 
tongkol dengan lama penggorengan yang berbeda tidak memberikan nilai yang berbeda. Abon yang dihasilkan memiliki nilai yang hampir sama. Hal ini dikarenakan formulasi pembuatan abon yang digunakan tetap, sehingga rasa yang dihasilkan hampir sama.

Berdasarkan perhitungan penerimaan konsumen terhadap organoleptik rasa menunjukkan bahwa lama penggorengan 40 menit terbaik yaitu sebesar 7,04 kemudian dibulatkan menjadi 7. Secara deskriptif, pada nilai tersebut dapat disimpulkan bahwa rasa abon ikan disukai panelis

\section{Tekstur}

Hasil uji organoleptik tekstur abon ikan tongkol yang menggunakan hasil samping kestrak minyak ikan berkisar antara 6,84 sampai dengan 5,72. Hasil analisis sidik ragam menunjukan bahwa perlakukan dengan lama penggorengan yang berbeda memberikan pengaruh yang sangat nyata terhadap parameter organoleptik tekstur. Hal ini dapat dilihat $\mathrm{F}$ hitung $>\mathrm{F}$ tabel $5 \%$, selanjutnya untuk mengetahui perbedaan dari masing-masing perlakuan dilanjutkan dengan uji BNJ. Rata-rata organoleptik rasa pada abon ikan tongkol yang menggunakan ampas sisa ekstrak minyak ikan dapat dilihat pada Gambar 7.

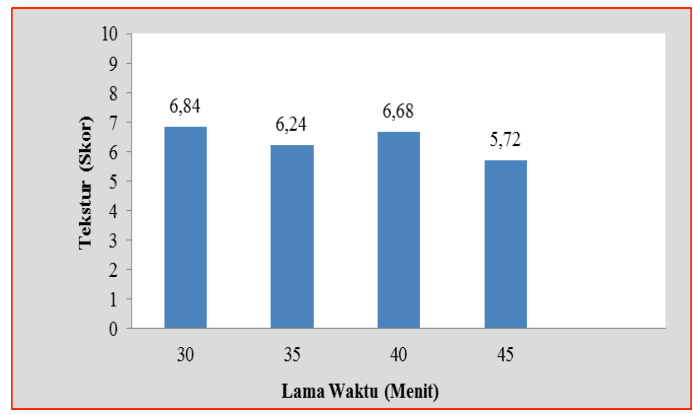

Gambar 7. Diagram rata-rata organoleptik tekstur abon ikan tongkol dengan perlakuan lama penggorengan

Berdasarkan Gambar 7 dapat dilihat bahwa organoleptik tekstur tertinggi terdapat pada perlakuan dengan lama penggorengan 30 menit yaitu sebesar 6,84 sedangkan yang terendah pada perlakuan dengan lama penggorengan 45 menit yaitu sebesar 5,72. Grafik tersebut terlihat bahwa panelis lebih menyukai tekstur abon ikan tongkol dengan lama penggorengan 30 menit.

Berdasarkan perhitungan penerimaan konsumen terhadap organoleptik tekstur menunjukkan bahwa lama penggorengan 30 menit terbaik yaitu sebesar 6,84 kemudian dibulatkan menjadi 7. Secara deskriptif, pada nilai tersebut dapat disimpulkan bahwa tekstur abon ikan disukai panelis.

\section{KESIMPULAN}

lama penggorengan yang terbaik untuk pembuatan abon ikan tongkol adalah selama 45 menit Karena berdasarkan uji terhadap parameter mutu kadar air, perlakuan tersebut memiliki nilai kadar air yang paling rendah.

\section{UCAPAN TERIMAKASIH}

Penulis menyampaikan terimakasih banyak kepada Sekolah Tinggi Perikanan dan Kelautan palu yang telah meberikan bantuan kepada penulis dalam melakukan penelitian.

\section{REFERENSI}

Aminah.S., 2009. Retensi Vitamin A oleh Tempe dan Minyak Goreng Curah pada Penggorengan Berulang Tesis

Apriyantono, A. Fardiaz., Puspitasari, N.L., S. Yasni, dan S. Budiyanto. 1989. Petunjuk Laboratorium Analisis Pangan. Pusat Antar Universitas Pangan dan Gizi. Institut Pertanian Bogor. Bogor.

Berghe J.P dan Branathan G, 2005. Fatty acids from lipids of marine organisms : molecular biodeversity, roles as biomarkers, biologically active compounds, and economical aspects. Adv. Biochem. Engin/biotecnol. 96 : 49-125.

Irawati. 2008. Modul Pengujian Mutu 1.Diploma IV PDPPTK VEDCA. Cianjur 
Ketaren, S. 1986. Minyak dan Lemak Pangan. Universitas Indonesia. Jakarta

Kusumayanti, Astuti, dan Broto 2011. Inovasi Pembuatan Abon Ikan Sebagai Salah Satu Teknologi Pengawetan Ikan. Program Diploma III Teknik Kimia Fakultas Teknik Undip Fakultas Teknik Universitas Negeri Semarang. GEMA TEKNOLOGI Vol. 16

Muchtadi TR.2008 . Teknologi Proses Pengolahan Pangan. Bogor : Institut Pertanian Bogor.

Rosyanti, R.S. 2000. Optimasi suhu dan waktu penggorengan hampa jamur tiram (Pleurotus ostreatus). Fakultas Teknologi Pertanian, IPB, Bogor
Sudarmadji, S., B. Haryono, Suhardi. 2007. Analisa Bahan Makanan dan Pertanian. Penerbit Liberty. Yogyakarta.

Standar Nasional Indonesia, 1995. Direktorat Jenderal Perikanan. Jakarta.

Winarno, F. G. 2002. Kimia Pangan dan Gizi. PT. Gramedia. Jakarta

Winarti, 2000. Pengaruh suhu dan waktu penggorengan hampa terhadap mutu keripik mangga Indramayu (Mangifera indica L.). Fakultas Teknologi Pertanian, IPB, Bogor.

Zura, C. F. 2006. Cita Rasa (Flavor). Departemen Kimia FMIPA. Universitas Sumatera Utara. Medan 